\title{
Taking Back Europe in Valdas Papievis's Novels
}

\author{
AUŠRA JURGUTIENĖ
}

\begin{abstract}
The novels of contemporary Lithuanian writer Valdas Papievis Eiti (To Go) and Odile, arba oro uostu vienatve (Odile, or the Solitude of Airports) are two of the most successful variants of Lithuanian literature elicited by globalisation and the end of the Cold War. Not only because after the fall of the Iron Curtain that divided the West and the East and the declaration of Lithuania's independence the author now lives and writes in Paris, but also due to the fact that his novels written in Lithuanian and describing contemporary Paris and Provence create topical and artistically mature narratives about the newest transformations of the European identity into an intermediate state.

The article discusses the author's uniquely romanticized tradition of existentialism and emphasises the moments of Lithuanian and French communication that establish the three main motifs of an individual's migration: home / to go / solitude, refining their existential and aesthetic meanings. The novels remind the reader that the forgotten natural and cosmic dimension of a human life is of no less importance than the social, historical and national environment determining it. The novels erase the ancient boundaries between the Eastern and Western European stereotypes; therefore, their French and Lithuanian origins are not noticeably in conflict, rather they merge into a common European memory, marked by sadness and disquietude.
\end{abstract}

Keywords: globalization; migration novel; intercultural dialogue; Lithuanian and French cultural relations; existentialism; European identity; Valdas Papievis

I live in agony, in yellow autumn Together with Europe in its throes of death.

(Jonas Aistis, “Jazz”, 1932)

\section{Introduction: Neither There nor Here but also There and Here}

Valdas Papievis (1962) is a graduate of the University of Vilnius in Lithuanian Philology and he worked at the University Rector's office. His first novel, Ruduo provincijoje (Autumn in the Provinces) appeared in 1989. After the declaration of independence of Lithuania, he first came to Paris in 1992 for a brief stay, only 
to return in 1995 to study the French language, and take classes in comparative literature at the Sorbonne. Papievis stayed on to work as a journalist for Radio Free Europe and continues to broadcast for Lithuanian Radio on French topics. Among the seven books (five novels and two collections of short stories) he published in Lithuania are two of his most successful novels, Eiti (To Go, 2010), and Odile, arba oro uostu vienatve (Odile, or the Solitude of Airports, 2015) that cross the usual boundaries of the emigration novel and deserve special attention ${ }^{1}$. One will not find any particularly dramatic conflicts, captivating action, compelling characters, topical political or social events in these two novels - no intriguing love triangles or postmodern irony. His novels obviously stand in ethical and aesthetic opposition to the predominant popculture marketing motto: “Tell me an enjoyable story and you'll get a good financial return!” Neither book contains anything that would guarantee a quick marketing success, and this is precisely why like some exotic plants they are unexpected, interesting and require special attention. According to the author, he is not a road builder, therefore, he is not paving any evident paths of action or thought (Papievis 2016). He is an author of labyrinth narratives and of metaphorical language that demonstrate the similarities in difference and the differences in similarities. The novels' narratives balance between poetic prose and existential essay, therefore they require slow reading.

According to Søren Frank's generalization in his book, Migration and Literature: Günter Grass, Milan Kundera, Salman Rushdie, and Jan Kjerstad (2008), the main literary protagonist of the $20^{\text {th }}$ century is ever more likely to be a migrant, evoking problems of national and cultural identity. Typical emigration novels, Lithuanian ones as well as those of other countries, usually are marked by social and cultural stereotypes: the characters move from an impoverished Eastern European or the Baltic republics (too often still identified as Russia) to the West, in search of a better life but not finding one. The narrative is predominantly dystopic, told from the first-person point of view. It is about

1 A fragment of the novel Odile, or the Loneliness of Airports by Valdas Papievis, introduced and translated into English by Karla Gruodis (http://vilniusreview.com/fiction/169valdas-papievis, 05.15.2019). Markus Roduner is translating this novel into German, while Dalija Epšteinaite has translated it into Russian. Eiti has been translated into French by Caroline Paliulis and has just been accepted for publication in France by Éditions Le Soupirail. Violeta Kelertas's English translation of the short story, Echo, or the Sieve of Time appeared in The Kenyon Review, July-August 2019 issue. In this article the quotes from Papievis's novels are translated by Alina Dailidenaitè. 
autobiographical experiences and difficulties in attempting to adapt abroad. ${ }^{2}$ In Lithuanian émigré literature two simplified alternative relations between a narrator and the motherland left behind have formed - either the native land is forgotten/ betrayed, or it is idealised and its loss is always mourned. Maybe this is why Papievis does not like his works to be identified with emigration and has declared: "I do not want to be an émigré." (Papievis 2015a) He constantly emphasizes his sense of an interim place - the time and state that he prefers most of all: "neither there, nor here, but also there and here, this but at the same time not this." (Papievis 2015a) Papievis feels at home in France, getting to know it, adopting its culture and liking its lifestyle, and in his native Lithuania as well, where he is receiving more and more recognition for his works. In 2016 he was awarded the Lithuanian National Prize for Culture and Arts for the expression of the existential experience and the renewed aesthetics of the novel. Therefore, he does not want to and cannot identify himself with only one of them. A different perception of emigration is closer to Papievis's heart, one that encourages individual freedom, when the distinctiveness of writing is shaped by cultural differences as well as the distance that one experiences from them, not allowing one to identify with either of them. The writer has assumed a position of partial distance and non-identification which opens up more possibilities to develop his individual freedom and a greater originality for his works. He gives a much broader existential and aesthetic meaning to contemporary migration ("to go") that we can confirm with a quote from another émigré writer, Joseph Brodsky, about the power of creativity to lead a person into a previously unseen and unique world: "Art is not a better but an alternative existence, it is not an attempt to run away from reality, on the contrary it is an attempt to give it life." (Brodsky 1987: 123)

When Lithuania re-established its independence in 1990, the dialectic relationship of an individual and the nation was intensely experienced by Papievis. The idea that there could be no free individual without a free nation, and there could be no free nation without the free consciousness

2 Lithuanian émigré prose: Gabija Grušaitë’s novels Neišsipildymas (Unfulfilment, 2010), Stasys Šaltoka: vieneri metai (translated as Cold East, 2018, 2019), Vaiva Rykštaitè's novel Kostiumu drama (Costume Drama, 2013), Dalia Staponkutë's book of essays Ǐ́ dviejų renkuosi trečią: mano mažoji odisejja (From the Two I Choose the Third: My Little Odyssey, 2014), Paulina Pukytës Bedalis ir labdarys (A Loser and a Do-Gooder, 2013), Birutè Jonuškaitës Baltu užtrauktukų tango (Tango of Zippers, 2009), Zita Čepaitès Emigrantès dienoraštis (Diary of an Immigrant, 2011), Ina Pukelytë’s Prancüziškas romanas (A French Novel, 2000), and others. The most critical theme of emigration is expressed in Marius Ivaškevičius's play Išvarymas (Expulsion). 
of an individual - this may have brought him closer to the tradition of French existentialism. If we perceive existentialism in its broad sense as the philosophy of individual freedom in everyday situations that was shaped by Jean-Paul Sartre, Albert Camus, Gabriel Marcel, we can find a great deal of it in Papievis's novels. His works also show how political changes after the Cold War are changing European identity after the USSR and the Marxist programme collapsed, Lithuanian independence was re-established, and the country together with the other Baltic Republics joined an enlarged European Union (2004). His narratives erase the clichéd boundary between Eastern and Western European stereotypes in as determined a way as in Mathias Enard's novel Compass which traces the inseparable historical relations of Western culture to the Orient. Torn apart by the Cold War, Europe in Papievis's novels meets at the most important existential locations. He creates his own existential variant of the common memory of European cultural history and gives an indirect answer to the "asymmetric European remembrance" which never reconciled the Eastern past with Western narratives, as Aleida Assmann has pointed out in her book, Der europäische Traum: Vier Lehren aus der Geschichte (2018).

\section{Paris - my City}

The French spirit of Papievis's novels has been mentioned by almost every critic who has written about him, the greatest Francophiles such as Violeta Kelertas (Kelertienè) and Vytautas Bikulčius among them. Distinctively provocative is a comment by Kelertienè on Odile or the Solitude of Airports' back cover: "you will not find anything Lithuanian in the book," indicating that not only are the characters French, but the narrator describes the streets and quarters of Paris that he knows so well and with such precision that one can call the city itself one of the more important characters in the novel. The entire work is dominated by the map of Paris and by its inhabitants. Two years after the death of Odile, the narrator remembers the last years of her life spent together: how often he would walk with her or push her wheelchair and take her promenading, he would move the furniture around in her spacious apartment, visit her neighbours and her friend Colette, he would spend time with her children - Eva and Henri when they come from England, he would live in the maid's room (chambre de bonne) rented from her, would see Emma and other friends, illegally work in Alain's antiques shop, travel to Rome with him. However, this description of an allegedly calm everyday life is deceptive, as everything is concentrated on the intense internal action of the narrator: 
A day off, free from the net of everyday worries; perhaps because one can experience beauty only during peaceful hours I always associate it with idleness. [...] Sometimes I think that perhaps we deride it out of fear: its beauty, if you experience it during lazy moments, not only fills you with the joy of being, but also saturates existence with absurdity and finiteness: falling into the abyss of nothingness, concealed around you and in you. (Papievis 2015b: 28)

In order to see the beauty that surrounds us better and to feel the Nothingness of one's life we have to stop being active, we need to learn how to slow down the pace of our lives: walk, not run. This is an aristocratic luxury, the privilege of an ageing person or a bohemian flâneur. Perhaps this is why the narrator of Papievis's novels is destined to meet mesdames who have great life experience, but no longer take part in active life?

In the other novel, To Go, the national identity of the characters and their cultural differences are of no great importance; outwardly the narrative is not impressive and is deliberately minimalistic. The narrator comes from an overcast Paris to sunny Provence for a week, having experienced a separation from his girlfriend and tortured by loneliness: "If someone could see him from a distance, they would think that this person is very lonely. But no one sees him, and he himself does not feel lonely. He has already forgotten what it means to be with people." (Papievis 2010: 69) When someone does notice the narrator and asks why he has come, he pretends to be the correspondent of a Lithuanian newspaper who is to write about fires in the Provence forests. In both novels the reader never learns the name of the narrator. In To Go the narrator cleverly camouflages himself with the phrase "the one who is staying at Anne's", and describes his true home by the verb "to go". Therefore, the beauty of Marquis de Sade's village, Bonbieux, the Venice of Provence, and other places in Provence the narrator knows so well spread out before the reader's eyes as if they were real. The text is full of French proper names and place names, the dialogues are moderately sprinkled with French phrases, it seems that the rosé wine often enjoyed by the narrator in the cafés could even have had promotional significance for readers in Lithuania ${ }^{3}$.

3 Un verre de rosé is contemplated from the point of view of phenomenology - as a substance perceived and sniffed, whose originality one doesn't want to desecrate by tasting, because it is more than a drink, it is the very spirit of Provence, in whose regard it is better to keep a respectful distance: "Perhaps for the reason that the longer you look at it [the goblet of rosé M.Ž], the more it seems that its resonating pink clarity is not only wine, but also the sadness of this province, saying adieu to you for one more day." (Žvirgždas 2011: 3-4) 
In both novels, besides the geography of Paris and Provence, the everyday life and characters of these places, there are deeper signs of French cultural influence that originates in the modern novel that opposes the realistic, plot-driven narrative which in turn comes from existentialism that denies rationalistic philosophy based on the objectivity of knowledge, the assumptions of historic progress, and especially during the time of the belle époque (18711914), demonstrates special sensitivity to the beauty of life and creativity (Claude Debussy, Eric Satie, Camille Saint-Saëns, Maurice Ravel in music, PaulAuguste Renoir, Edgar Degas, Paul Cézanne, Henri de Toulouse-Lautrec, Pablo Picasso, Amedeo Modigliani, Henri Matisse in painting, Charles Baudelaire, Paul Claudel, Maurice Maeterlinck, Marcel Proust, Stéphane Mallarmé in books).

\section{My Language is the Lithuanian Language}

No matter how broadly the novels embrace France, the claim that there is nothing Lithuanian in them is not be true. After all they are written in Lithuanian which for Papievis is not only a tool of narration but also another very important participant in the narrative. The writer who lives in a modest attic apartment near the Cluny Museum in Paris declares: "Apart from words I have nothing." (a quote by Papievis from Grinevičiūte 2017) The Paris he describes and all the French characters are clothed in Lithuanian. In Papievis's novel, however, France is filtered not only through the Lithuanian language. The Lithuanian language is not only the body of the narrative, it has become part and parcel of the narrator's sensibility and experiences: "The word, the language, its rhythm reveal something I never knew was in me." (Papievis 2015a) The novels are dominated by a world fabricated from the narrator's language and imagination, legitimising the play of the recognisable and the created, common and celebratory things. The narrator of the novels is ambiguous: both are limited by specific daily situations, and transfused by sadness and transcendent feelings incomprehensible to him. The language leads him away from the visible external reality of life and takes him to the greater invisible internal reality - in this kind of language the Symbolists created poetry and the existentialists wrote philosophical essays:

Behind my back I hear again the wheels of the suitcase rattling. The endless corridors of airports - like the inexhaustible solitude of airports. Your true existence, hidden by the everyday of the present. The time to infinity is extended, but one is not allowed to forget it. (Papievis 2015b: 7) 
JURGUTIENE

For this reason Kelertiene observes: "The readers of the novel about Paris and Odile will experience the unique pleasure of reading which was called jouissance by Roland Barthes." (Papievis: 2016: back cover) According to Papievis, described reality is only the clay from which a pitcher (a work of art) is made. His perfected sense of the Lithuanian language enables the writer to display its aesthetic power: "The only thing that one can rely on, for me, is language. When I begin to get the impression that it itself is doing the talking, when a rhythm appears that is stronger than my will and starts to lead me, I feel a bit more secure." (Papievis 2015a) Papievis's statement about the language's rhythm which seduces his own writing's resolve can also be applied to the reader of his novels whose will is captivated by the same rhythm, making his imagination dance, freeing his fantasy, forcing him to face existence itself.

Papievis's literary language contains quite a few signs of $20^{\text {th }}$-century Lithuanian modernist literature. The authors of this literature experienced a strong impact from French literature when after the Second World War they became exiles in Europe (Antanas Vaičiulaitis, Jonas Aistis, Alfonsas NykaNiliūnas, the semiotic theorist A. J. Greimas) ${ }^{4}$. A number of generations of Lithuanian writers yielded to the myth of Paris, the world capital of culture in those days. Papievis's prose can be linked to Aistis's neo-romantic poetry which balances between the romantic perception of sadness (the relationship with one's self described emotionally) and the experienced phenomenological projection into the world of language (when existence becomes relevant for the writer and the mystical sense of Paradise fades away). Aistis's poetry was described in terms Nyka-Niliūnas invented: "Where his word is 'phenomenologically naked', this is where it captivates and is identical to pure poetry." (Skrupskelyte 1990: 163) These links appear in Papievis's prose as well: the same openness to existence, born spontaneously when consciousness merges with the experienced world, the same catastrophist sense of Europe, the same proximity to French culture, the same attention to literary form. Not so much psychology and aesthetics as phenomenological openness towards existence connects both writers to the tradition of romantic modernism ${ }^{5}$.

A Lithuanian spirit in Papievis's novels resembles invisible but everpresent air which is essential for existence; it gains original and mature stylistic expression that refuses straightforward national rhetoric and primitive national

\footnotetext{
See Klišienè 2009.

5 The remains of romanticism in Lithuanian prose are noteworthy in texts by Vaižgantas, Vaičiulaitis, Andriušis, Papievis, etc. In France these had been legitimized by JorisKarl Huysmans as a realism expanded by the spirit.
} 
Taking Back Europe in Valdas Papievis's Novels

egotism and exoticism. Perhaps for this reason the French and Lithuanian elements do not conflict with one another in Papievis's novels; they melt into a common European memory, marked by sadness and anxiety.

\section{The Existential Dimension of the Novels}

Papievis's individual is interesting because neither national nor social nor historical circumstances are able to determine him since the dimensions of inner life and freedom are most important to him. This was called soul by the Romantics, magical realism in $20^{\text {th }}$-century prose and Dasein, being-inthe-world, in existential philosophy. The impulse of Papievis's novels and the action of the plots are experiences of the existential state common to all human beings, and have been addressed a number of times in different interviews by the writer:

I do not like using the concept "Writing is an existential state". However, it is a state when you distance yourself from the world and all its people, from everything that is around you, yet at the same time you most strongly coincide with everything, open up to the world, and it opens up to you. Absolute loneliness, and absolute blending with everything. (Papievis, quote from Briedienè 2018)

This can be compared to a very similar statement by Sartre: "Consciousness and the world are given at one stroke: essentially external to consciousness, the world is nevertheless essentially relative to consciousness" (Sartre 1939).

According to the German phenomenologist Wolfgang Iser, in general the driving force of writing originates from the indestructible uncertainty of duality and complicated identity: from the tension of the real and the created world, when one wants to repeat oneself (mimesis) and at the same time deny/ vary oneself (fiction) (Iser 2002: 205). Writing originates not from the conscious needs or aims of a writer but only from the mentioned tension that constantly merely broadens and reshapes the diversity of the world without providing it with any stronger foundation or a more convincing explanation. Thus, the motif of emigration in both novels has a keyword to go/ to leave and gains a special existential meaning, claiming that the ever-changing human identity and inexplicability of the world reveal themselves best in creative work:

You speak as if there were places in the world that you know well. As if there were people in the world that you are able to say something certain about $(\mathrm{Pa}-$ pievis 2010: 101). 
JURGUTIENE

Could it be that only in dreams can you understand the secrets of this world? If it is possible to understand secrets at all. Maybe secrets are there to not be understood? If you understand a secret, maybe it wasn't even a secret? (Papievis 2010: 152)

The writer relates the topic of secrets of human life not only to the existential questioning of rational knowledge but also to the motif of silence characteristic of Eastern art (the inability to put life into words) and Eastern aesthetics in general which embraces minimalism of form and ambiguity of meaning:

Nothing will change..

And while you are still here...

And when you will not be...

And now stay quiet.

And close your eyes.

Listen.

To the silence.

To.

The silence...

and to nothing.

Now just listen. (Papievis 2010: 58-59)

Of all living languages, the Baltic (Lithuanian and Latvian) languages have retained most their Indo-European features and are closest to Sanskrit in which the ancient holy Indian texts, the Vedas and the epics, the Ramayana and the Mahabharata are written. ${ }^{6}$ This archaic quality of the language was one of the factors that determining the constant attention of Lithuanian writers, including Papievis, to Eastern cultures. (Kubilius 1983: 65-112)

Both novels are intensely filled with the sense of existential time. It is as if the writer were coming from another world and was very much surprised by the early readers of his novel Odile, or the Solitude of Airports, who called his book "an ode to old age" and praised his skill in describing the life of an ageing woman. There is no doubt that the book contains such aspects but the narrative

6 For example, the writer found it of interest that the Lithuanian language has more than 70 words to describe human movement, but compared to the French language, it has many fewer words to describe colors. For more about the archaic features of the Lithuanian language, see Bopp 1985 (the 1845-53 English translation of Franz Bopp's Comparative Grammar of the Sanscrit, Zend, Greek, Latin, Lithuanian, Gothic, German and Slavonic Languages) and Subačius 2018. 
takes us somewhere else - to vanishing existential time, shared by people of any country, culture or age.

The image of home is important in both novels. It is related not to the traditional idea of putting down roots in one place, but to its opposite - the ability of a human being to go, to move in the trajectories of space and time, to live with an open heart and open eyes. The always changing horizon of understanding of the narrator (constantly differing descriptions of objects, people, nature) is the actual plot of the novels. An equation sign placed between the concepts of home and go indicates that the narrator is constantly shaping his life, a concept that derives from existentialism:

To go is my home. It is more real than a house with a foundation, a roof, walls. A house having a foundation, a roof and walls is imaginary. You just have to stop, settle down and you'll lose your home [...]. It is a temporary shelter; your real home is to go. To go and go. Without stopping. No one will threaten this house of yours, no one can destroy or burn it down. And in it you are impossible to reach. You will be like a bird perching on the line of the horizon - distancing itself as the sight approaches it. (Papievis 2010: 57)

The same perception of home can be found in an early essay by Jean-Paul Sartre Une idée fondamentale de la phénoménologie de Husserl: l'intentionnalité (Intentionality: the Fundamental Idea of Husserl's Phenomenology), where the closed state of a human consciousness is compared to non-existence, while human existence (like the indestructible integrity between the subject and the object) is described by the metaphor of walking along a dusty road ("It is not in some hiding place that we will discover ourselves; it is on the road, in town, in the midst of a crowd, a thing among things, a human among humans").

Nevertheless, Papievis rewrites the categories of existential nausea, rebellion, and the absurd in his own fashion, using a gentler poetic language, and supplements it from his own romantic tradition with the categories mentioned, the ones of the world's beauty and existential fulfilment, claiming the unity of man with nature and the cosmic universe. The existential drama of life is suppressed by a melancholy narrative intonation. It is not in vain that the writer ascribes an original metaphor to time as "an existential nettle", while the narrator sees himself as the prince of sorrow and eeriness accompanied by the Unicorn and listening to a lonely dog howling on the edges of outer space. Isn't this why in both novels the dominating to go motif is also reminiscent of many old pilgrims, romantic travellers, or Baudelaire's flâneur?

The picture of Odile is romanticized even more than is the narrator: from childhood Odile was in poor health but led an active inner life, she painted, 
JURGUTIENE

published stories, one of which is about the trip of Ana Maria from her parents' home to a mountain resort, and her first love is retold by the narrator who, charmed by her unusual sensuality, intertwines it into his narrative. Of course, she liked the romantics, had meditated at the grave of Chateaubriand and expressed her boredom in her diary; while representing her calm and rich family life, she sometimes liked adventures and turning sauvage. When on her birthday her son invited her to climb through the attic window and go to the roof, she looked down at the shining city and was stunned into saying, "I have never seen Paris more beautiful than this evening from the roof. I have never received a more beautiful birthday present. This is not a birthday celebration; this is the celebration of my life." (Papievis 2015b: 237) The narrator, affected by Odile's actions and his memories of her, repeats the same phrases after her death. Looking from the roof into the dizzying infinity of the sky and the panorama of the city, he is overwhelmed by an unusual but very strong desire to apologise to everyone, to forgive everyone he had ever hurt and to reconcile with everyone:

$[. .$.$] in that hour I experienced all this nonsense: they clutched my throat, they$ made my head spin and my soul tremble - I wanted to hug the entire world, I mourned for Odile and at the same time for the entire world. (Papievis 2015b: 277)

The narrator and the characters can combat the attraction of their earthly home, they can push off from it and experience the secret transformations of existence by rare but important experiences of dreams, creativity or death, sometimes all merging into one:

One just has to make up one's mind and be brave, just have no fear to gain the momentum. You run and run, with all your might until you're out of breath and start suffocating, and it seems to you that you won't make it, your lungs will burst, then like a bird or an airplane its wings you stretch out your arms - you don't need to do anything else, the sky itself will lift you up from the earth. [...] To be able to take off, to escape from the gravity of the Earth, you need to choke on everything, on your own life. [...] What hubris to want to understand the world, if the universe from which it originated doesn't understand it or itself either, all that's left for it, like for us, is only to wonder at it. (Papievis 2015b: 303-304)

The image of the white silk drapes in Odile's apartment which is repeated in the novel also becomes a romantic symbol - the screen, which means that the most important things in life are not to be easily seen. On this side of the screen, life 
is very substantial and ordinary, in the form of city streets, shops, cafés, squares and bridges, whereas on its other side is the most important, but unknowable, infinite and boundless presence of the universe waiting for everyone: " putting your head back, you can see the sky and the clouds reproachfully proclaiming to you that there is more than you can see, feel or smell. Yet you will never hear the music of the sky's spheres. Yet you will never understand the sky's choreography." (Papievis 2015b: 200)

The narrator, who appreciates art as the paramount and most meaningful expression of a human life, shares a very romantic perception of beauty: "Even more so for the reason that I always relate evil and pain with beauty, I most probably should go to the psy" (Papievis 2015b: 194). To understand the beauty of the world as inseparable from death and sadness is what Edgar Allan Poe and Charles Baudelaire taught writers. The novel To Go is related to Wong Kar-Wai's music for the movie In the Mood for Love whose motif the narrator interprets as follows: "[A]s if the entire world were slowly sinking into the sea. The sunset is gradual after which no morning will dawn. Maybe it's always like that - when we ourselves collapse it seems that the entire world collapses with us." (Papievis 2010: 8) A musical motif like this also helps to connect the contrasting experiences of the world's beauty and its sadness passing by. A constantly repeated, short but all-encompassing formula, created according to the principle of contrast, is used to express the experience of beauty: "All this splendour before the end." (Papievis 2010: 118) On Papievis's narrator's horizon the world always flames with the enchanting beauty of a farewell. No matter what it is, whether a deceased woman that he cared for or the blooming flower he noticed or a village bridge, reminding him of Roman times, or the sky seen through the branches of a cedar tree, or his grandparents' garden he dreamed of. All that you see and what you become emotionally attached to is temporary and meant for mourning:

He bent down and without touching embraced everything with his palms. Polished by the moonlight, the flowers shimmered in silver. The embodiment of circular symmetry, rigid and loose at the same time, destroyed at a mere touch, it was glowing with the sad condemnation of its mortal beauty [...] as everything is a constant disintegration, as everything is unavoidably sliding to its end. (Papievis 2010: 32-33)

In the novel To Go the hostess Anne, who accommodated the narrator for a week, her daughter Elisabeth, the neighbour Dorothée, other less visible characters (Angelo, Pierre, Serge, Nathali, Jacques) - seem to be accidentally brought together by fate. But this is so only at first glance. Indeed, all and 
JURGUTIENÉ

everything in this novel is perfectly united by the most important existential theme of solitude. It is existential because it is impossible to avoid it or relate it only to the state of the narrator, a Lithuanian immigrant. No less typical is the feeling of solitude that has become almost a part of the two neighbours from Provence who have never stepped outside Provence, who were former friends but no longer talk to each other: "But how can they be close to him, if they are so distant to one another? Like connecting vessels which contain the same sadness. But they are little glass tubes, parallel to infinity." (Papievis 2010: 23)

In the novel Odile or the Solitude of Airports, written after the novel To Go, it seems as if the author is looking more determinedly for ways to deal with the solitude of the characters, even though the name of the novel contains the existential motif of loneliness. In the centre of the novel is the story of the friendship between the narrator and Odile, ending with the sadness at her loss. The motifs of leaving, trips, flight and solitude are very simple but existentially extended and knot the lives of the young narrator and the failing Odile together despite their great difference in age: "embracing our short lives here and maybe very long somewhere else, we people, all together and each one separately, are flying." (Papievis 2015b: 305) The novels of Papievis suggest that the world is given to man not to be understood, but for him to learn to observe it, to be fascinated by it, to feel its cosmic infinity and thus to be more attentive and sensitive to the people that we meet. In the novel Odile, or the Solitude of Airports the opportunity is presented for such spiritual soulmates to find each other: she recites Baudelaire to him, and he sees her as if she had stepped out of the novels of Proust - an elegant elderly lady. Even though she is elderly (madame, la petite dame), she represents a French upper-class lifestyle and high culture, while her tenant and carer, a young newcomer (mon cher garçon, domestique) has almost nothing except his unhappy love and the homeland he left. However, their different social and national stereotypes lose importance when they are united by their similar interest in art, their sensitive hearts and their feeling that time and life are passing by: we are all visiteurs in this world.

This relentless longing for time past that made all European romantics suffer gained a modern form of narration in the novels of Marcel Proust; it reigns at the centre of Papievis's novels as well. Romantic visual memory, according to Frances Ferguson who researched it in Solitude and the Sublime: Romanticism and the Aesthetics of Individuation (1992), is meant not for preserving the most cherished spiritual things from oblivion but for uncovering the endless abyss that separates the past from the present, to witness that it is alien to the consumer society's glamour and poverty. Therefore, Papievis's characters are doomed to nostalgia, while melancholy intonation is infuses every sentence: 
Taking Back Europe in Valdas Papievis's Novels

I think I would like to go back to the times that Odile wrote about [...], when it seems, at least when reading Odile's story, everything was a bit delicate, more fragile, more subtle, and so what if it was a little more sad. (Papievis 2015b: 183)

This is how historical time is introduced into Papievis novels, by thinking in a slightly old-fashioned way that the best times have already gone by. The novel To Go starts on a sad note that people had to go from la belle époque to dig the trenches of World War I. In the other novel, Odile's ageing disability is related to the disability of the present time. The joy about the end of the Cold War cannot last long, as all calm times spoil a person and bring the threat of war closer: "I look at ailing people when I think about this time of ours, ailing and having no desire to cure itself." (Papievis 2015b: 189)

Papievis is searching for cracks in the post-industrial world that is experiencing the globalisation crises and shaping narratives about the possibility of bringing different people together. He manages to write about it without any postmodern irony and cheap sentimentality that is rarely found. There are only a few hints about "attacks of lyrical hysteria" or " $p s y$ " that demonstrate the talent of the author in managing to control the emotional intonation of the narration by protecting himself from melodrama. His characters are deliberately reserved, they avoid expressing their feelings. "Our lives hardly touch" (Papievis 2015b: 58) - this is the most and the best they can do, when they sip whisky in the evenings and walk the promenades of the Luxembourg gardens: "when we'd look into the sky in silence - it seemed to me that we are related by the same sadness of the past day, the painfully aching evening, when the day is almost, but not fully over." (Papievis 2015b: 200) The novel is about how important it is to retain the sensitivity of mutual relations in the globalised world that is losing it, where financial interests, preconceived assumptions, the cult of youth, speed, things and money prevail.

The fractured nameless narrator intelligently introduced by the author also helps to avoid sentimentality in the novels. Even though everything is coloured by loneliness, sadness and the perceptions of the narrator, quite often the narrator is playfully duplicated and manages to look at himself as an alien, shifting from the central first person (I) to the second person (you) and the even more distant third person (he) and the generalising first person plural (we), in this fashion opening the perspectives of multi-layered relationships with himself and the reader:

...this full moon at last hears the scream of your soul and starts approaching you slowly on a foggy moonlit path like the motherland which, tempted by 
foreign lands, you left once upon a time, and which like a mother is forgiving and takes pity on you and returns you to her embrace - you look at the disc of the full moon and you would like its path to be faster, you haven't learnt how to be patient, you encourage and beg it to hurry. (Papievis 2015b: 190)

From his very first novel, Autumn in the Provinces (1989) Papievis's individual style was distinguished by its use of metaphor, musicality, and at times even a surplus of stylistic subtlety. In both of his best novels under discussion here, his poetic language gained a new existential depth and justification - when next to the beauty of the pictures of the world he demonstrates, one can more clearly see the contrast of their vanishing black shadow and the unfilled spaces of cosmic emptiness. It is quite obvious that his encounter with the painter Pranas Gailius (1928-2015), who had also fled to Paris from Soviet-occupied Lithuania after World War II, had a major influence on him. They would get together in Paris and in Gailius's summer studio in Provence. Papievis did some very revealing published interviews with Gailius about the latter's ideas on art, and used his works for almost all his covers after their meeting. Gailius even made special illustrations for the book To Go. Gailius's abstract expressionist illustrations for both novels organically transform existence with various natural forms and blend with the stylistics of Japanese engravings. Gailius's artistic philosophy about "Sensitive Surfaces" (Surface émue. Série de ville d'Avray), comparing them to a wound, was very close to the world created by Papievis ${ }^{7}$. A wound is a locus of phenomenological collision - it is that our consciousness congruently melds (integrates) with the world, yet it remains alien to it, and thereby has lost the meaning of psychological suffering it had previously. Both artists have the same creative programme, namely to detect that which is covered and hidden:

Why is everything I see just a picture to me, mounted in frames of uncertainty, where people are like matches still barely smouldering, but soon they will be extinguished and fall into the abyss, as black as their little heads? Maybe it will not be them, maybe it will be myself? Not soon, but already now. (Papievis 2010: 48)

In Papievis's sentences the visible external and the invisible internal worlds feed one another, creating a peculiar impression of a lunatic language and visions of

\footnotetext{
Papievis: “You painted many works, which you label 'sensitive surfaces.' Is painting for you a sensitive surface?

Gailius: "That is what I am. [...] In reality all painting is a sensitive surface. Sometimes it can be like a wound." (from an interview with Pranas Gailius, Papievis 2003).
} 
romanticized landscapes: "What other home can you possibly need, if you have this palace of the night - a foundation without any illusions, it's not partitioned into halls of hope and hopelessness, reflecting your soul rather than your face in their huge mirrors?" (Papievis 2015b: 89) Papievis's novels constantly remind the reader that the forgotten natural and cosmic dimension of a human life is no less important than the social and historical environment determining it.

\section{Conclusions}

In the global world with the social divide deepening, national conflicts and the insecurity, Papievis resorts to the principle of contrast to describe the life of a contemporary person: he demonstrates its difficulty ("The quotidian - is a railing to which she is holding onto as hard as she can. But isn't that the case for us all, the same - for all of us?” (Papievis 2010: 24)) and concurrently he is determined to defend the value of the individual not in terms of what he is now, but in terms of what he would like to be, and in this way he returns us to neo-romantic and existentialist traditions, obtained from contact between the differing French and Lithuanian cultures.

By focusing on various characters who each survived the same existential brevity of life and solitude, the novels gain a generalizing meaning, intended for an ethical analysis of the relationship with the other. The narrator feels the greatest anxiety because in this contemporary globalised age the most important thing is neglected; i.e. sensitivity to the other and to the person who is different that art helps to disclose best of all:

But why is everything ordered this way, why does energy find its road lying smoothly ahead without any scruples or effort on its part, while sensitivity, longing, anxiety - all that the arts express best and that which in reality nourishes the world's soul is left by the wayside? (Papievis 2015b: 130)

Papievis's novels are global and undoubtedly this is confirmed by the author's residing in Paris, and the critics endlessly questioning him about how Lithuanian or French he is. In this article, the objective was to show how the author is able to integrate different national and cultural phenomena, how he recovers a Europe torn apart by the Cold War, without denying his nationality and continuing to write in his native language, but also expressing his anxiety with regard to the common European fate. By inscribing his nationality very organically into the universal context, and opening the projection of cosmic space into an individual's social life, he creates a unique prognosis for an 
JURGUTIENE

integral European identity. Therefore, the provocative post-colonial questions, such as to what extent his novels make Europe "provincial" and make Lithuania "European" (Hutchinson 2018: 94-96), lose their meaning. Hans Georg Gadamer has said that Europe is exceptional in the diversity of its cultures. "But what are we going to do with this inherited diversity? Will we focus on the essentialist cultural variety promoted by multiculturalism, strengthen our defensive trenches and thus ensure our national security? Or with difficulty will we be looking for a dialogue of diverse cultures and nurturing feelings of integration acceptable to all in our common home?" (Bauman 2015: 104-105) Even though the current situation in Europe is unclear and even catastrophic, as no one knows where it is going to take us, Papievis's books like the ones of many Latin American, Irish, or Eastern European intellectual migrants to Paris (Julio Cortázar, James Joyce, Samuel Beckett, Czesław Miłosz, Milan Kundera, etc.) take the reader on the road to integration of different cultures.

\author{
Aušra Jurgutienè \\ ausra.jurgutiene@gmail.com \\ Lietuvių literatūros ir tautosakos institutas \\ Antakalnio g. 6 \\ LT-10308 Vilnius \\ LIETUVA / LITHUANIA
}

\title{
References
}

Assmann, A. 2019. Go East! - https://www.eurozine.com/go-east/ (10.05.2019).

Assmann, A. 2018. Der europäische Traum: Vier Lehren aus der Geschichte. München: C.H. Beck.

Bauman, Z. 2015. Kultūra lakiojoje modernybeje. Trans. Kęstas Kirtiklis. Vilnius: Apostrofa.

Bikulčius, V. Prancūziškos dvasios romanas. - http://www.skrastas.lt/?data=2015-1103\&rub=1146671142\&id=1443108206\&pried=2015-09-25 (24.05.2019).

Bikulčius, V. 2015. Lietuvis Paryžiuje: tarp manijos ir filijos. - Literatūra, 57(4), 97105. https://doi.org/10.15388/Litera.2015.4.9808

Bopp, F. 1985. A Comparative Grammar of the Sanscrit, Zend, Greek, Latin, Lithuanian, Gothic, German and Slavonic Languages. Transl. Ed. B. Eastwick. Hildesheim: Olms.

Briedienė, R. 2018. Rašytojas Valdas Papievis susitinka su skaitytojais. - http:// lituanistusamburis.lt/rasytojas-valdas-papievis-susitinka-su-skaitytojais/ (19.04. 2019). 
Taking Back Europe in Valdas Papievis's Novels

Brodsky, J. 1987. The Child of Civilization. - J. Brodsky, Less Than One: Selected Essays. New York: Farrar, Straus and Giroux, 123.

Enard, M. 2019. Kompasas. Trans. Violeta Tauragienè. Vilnius: Baltos lankos.

Ferguson, F. 1992. Solitude and the Sublime: Romanticism and the Aesthetics of Individuation. Routledge.

Frank, S. 2008. Migration and Literature: Günter Grass, Milan Kundera, Salman Rushdie, and Jan Kjerstad. New York: Palgrave Macmillan.

Grinevičiūtė, A. 2017. Rašytojas V. Papievis: "Kalba yra mano namai”. - Bernardinai. lt, http://www.bernardinai.lt/straipsnis/2017-06-02-rasytojas-v-papievis-lietuviukalba-yra-mano-namai/160115 (25.06.2018).

Horn, E. 2018. The Future as Catastrophe. Imagining Disaster in the Modern Age. Trans. Valentine Pakis. Columbia University Press.

Hutchinson, B. 2018. Comparative Literature: A Very Short Introduction. Oxford University Press.

Iser, W. 2002. Fiktyvumas ir ịsivaizdavimas: Literatūrinès antropologijos perspektyvos. Trans. Laimantas Jonušys. Vilnius: Aidai/ALK.

Klišienė, N. 2009. XX a. 4- to dešimtmečio lietuvių literatūra: prancūziškieji kontekstai. [20th-century Lithuanian Literature of the 1940s: French Contexts.] PhD Diss. Vilnius University.

Kubilius, V. 1983. Lietuvių literatūra ir pasaulinès literatūros procesas, Vilnius: Vaga.

Nyka-Niliūnas, A. 1988. Jono Aisčio poezijos parašteje. - Jonas Aistis. - Raštai, v. 1: Poezija. Chicago: Ateities Literatūros Fondas, 400-415.

Papievis, V. 2003. Menininkas be pavardès. Pokalbis su dailininku Pranu Gailiumi. - 7 meno dienos, 19.09, https://www.7md.lt/archyvas.php?leid_id=581\&str_id=2394 (18.10.2019).

Papievis, V. 2010. Eiti. Vilnius: Lietuvos rašytojų sąjungos leidykla.

Papievis, V. 2015a. R. Jonikaitès pokalbis su Papieviu. - LRT "Literatūros akiračiai”, https://www.lrt.lt/mediateka/irasas/1011927748/literaturos-akiraciai2015-09-13-17-03 (05.02.2018).

Papievis, V. 2015b. Odile, arba oro uostu vienatvė. Vilnius: Alma littera.

Papievis, V. 2016. “Žinių radijas”, M. Gailiaus pokalbis su Papieviu "Kai knygos prabyla”, https://www.youtube.com/watch?v=K0MvPabOuCc (05.05.2019).

Sartre, J.-P. Intentionality: the Fundamental Idea of Husserl's Phenomenology. - http:// www.stephenhicks.org/wp-content/uploads/2016/05/Sartre-JP-HusserlIntentionality.pdf (10.06.2019).

Skrupskelytè, V. 1990. Jono Aisčio Raštų pirmas tomas. - Aidai, 2, 159-165, http:// www.aidai.eu/index.php?option $=$ com_content $\& v i e w=\operatorname{article} \& \mathrm{id}=7641: \mathrm{kn} \&$ catid $=$ 441:2\&Itemid=487 (05.05.2019).

Subačius, G. 2018. Lietuvių kalba: nepatogus unikalumas. - https://www.academia. edu/37311555/_Lietuvi\%C5\%B3_kalba_nepatogus_unikalumas._The_Lithuanian Language_Inconvenient_Uniqueness._Passport_2_Lietuvos_tapatyb\%C4\%97_ vakar_\%C5\%Aliandien_rytoj (18.10.2019).

Žvirgždas, M. 2011. Ties kosmosu palinkus [Eiti]. - Knygu aidai, 2, 1-5.

Žvirgždas, M. 2015. Neišsipildžiusio gyvenimo prabanga. - Knygu aidai, 4, 1-8. 